\title{
HISTORY AND MYTH IN AFTER THE DEATH OF DON JUAN
}

\author{
Mercedes Aguirre
}

Sylvia Townsend Warner's novel Afier the Death of Don Juan (1938) reflects her views on the "political chemistry" of the Spanish Civil War'. Warner started drafting Afier the Death of Don Juan after her last trip to Spain in the summer of 1937, when the war was still on-going and its outcome uncertain; however, the tragic end of the novel foretold the demise of the Spanish Republic, and a 1939 advertisement for the novel even called the work 'prophetic' (New York Times Book Review 5 February 1939 p.9). This articie tries to throw light on some of the literary and historical foundations that informed and influenced the writing of After the Death of Don Juan. It considers the novel as part of the centuries-long myth of Don Juan (or Don Giovanni), which began in the seventeenth century with Tirso de Molina's play El Burlador de Sevilla y Convidado de Piedra (1630). It also argues that the ending of After the Death of Don. Juan was inspired by a battle of the Civil War that was covered extensively in the international press: the siege of the 
Alcázar of Toledo. By using the Don Juan myth as the narrative point of departure of the novel, and focusing on the central episode of the siege of Don Saturno's castle, Warner depicted the Civil War as primarily a class war. The novel, which portrays Spain as a country torn between tradition and backwardness, revolves around two key themes: the tension between tradition and progress, and the search for national identity in times of political crisis.

After the Death of Don Juan is a distinctive addition to the long list of literary works that since the seventeenth century have explored the myth of Don Giovanni. Beginning with Tirso de Molina's 1630 play, the legend was famously rewritten by Molière (Dom Juan oul Le Festin de Pierre, 1665), Mozart and Da Ponte (Don Giovanni, 1787), and Byron (Don Juan, 1819), among many other recreations. As evidenced by her letters with her friend and fellow writer Nancy Cunard, Sylvia Townsend Wamer conceived of her novel as a political fable (Schmidt and Warner 2002, p.45) forming part of the Don Juan tradition. In addition to bcing acquainted with the versions by Molic̀re, and Mozart and Da Ponte, Warner may have read Tirso de Molina's seventeenthcentury play in Spanish, since it was available in the London Library, of which she was a frequent user. While she was not proficient in the language she seems to have approached foreign-language texts as a scholar, and she also translated several Spanish war romances into English ${ }^{2}$. In any case, Warner seems to have been aware of the existence of the Spanish versions of the myth, since she borrowed the original surname of Don Juan to name the village in her novel, Tenorio, a name that only appears in Tirso's original play and in José Zorrilla's nineteenth century version Don Juan Tenorio (1844).

Warner's novel continues the story of Don Juan as recreated by Mozart and Da Ponte's opera Don Giovamni, which premiered in Prague in 1787. The opera concludes with Don Juan being sent to Hell as a punishment for having seduced several women, as well as having killed the father of his last conquest, Doña Ana. At the 
bcginning of Warner's novel we learn that Dona Ana, now married, has not forgotten Don Juan. She convinces her husband to travel to Don Juan's place of birth, the village of Tenorio Viejo, in order to break the news of the libertine's death to his father Don Saturno. Dona Ana, who has a premonition that Don Juan is not dead, insists on extending their stay, to the dismay of Don Saturno. The story of the inhabitants of the castle is from then on intertwined with those of the villagers, who, dissatisfied with their living conditions, are trying to convince Don Saturno to fund a much needed irrigation scheme. In the last third of the book Don Juan finally reappears, his death proving only a trick to avoid his persecutors and conceal an embarrassing disfiguring illness. The peasants, thinking that the return of the heir of the castle will only perpetuate their situation, decide to rebel and besiege the fortification. The poignant end of the novel sees the failure of the rebellion of the villagers, whose leader is killed in the battle, while Don Juan, once again, manages to dodge death.

Continuing Mozart and Da Ponte's eighteenth century re-interpretation of the myth of Don Juan allowed Sylvia Townsend Warner to present her allegory of Spain as a quasi-feudal society, stressing class difference and the exploitation of the peasants as the main source of conflict. The argument of the novel is coherent with Warner's belief that the underlying conflict of the Spanish War was class inequality rather than opposing political ideologies. As she stated in a letter to Valentine Ackland: 'This war in Spain is not a Spanish Civil War (what the Govt and $B B C$ have taught us to call it). It is an international war, and it is a class war. It is a conflict between a ruling caste, and the people.' (Harman 1989, p.172). Jan Montefiore has pointed out how the characters in the novel are 'social types' (1996, p.160), representing the social groups participating in the Spanish Civil War. The liberal and progressive bourgeoisie, which propelled the creation of the Republic, is represented by Don Saturno. The nobility, which appears as ridiculously obsolete and is strongly against social reform, is represented by Don Ottavio and 
Doña Ana. The couple's entourage, Doña Pilar and Don Isidro, are traces of the dramatic origins of the myth. They often appear or leave the scene in pairs, and essentially provide aside comments or comic relief. The Catholic Church, heavily criticized in the novel, is primarily represented by the ruthless sacristan Don Gil and the oblivious priest Don Tomas, while the oppressed peasants find their voice in characters such as Diego and Ramon.

Warner's title character represents a deviation from the Don Juan tradition. The works of Tirso de Molina and Molière, perhaps unintentionally, evoked a certain sympathy and even admiration for the reckless and ingenious libertine, despite his selfish and despicable behaviour. Don Juan was implicitly seen as rebelling against social mores, in the case of Tirso's play, or more explicitly against religious belief, in the case of Moliere's atheist protagonist. Crucially, Warner's Don Juan swiftly goes from being a libertine to becoming an oppressor. a tyrant. A traditionally anarchic and transgressive figure is now used as an emblem for Fascism in the author's complex Spanish Civil War allegory. If Mozart and Da Ponte had already presented Don Giovanni at his most cruel, problematizing the audience's wish to see Don Juan as an appealing anti-hero, Warner's Don Juan has no redeeming qualities, not even the cunning and shrewd intelligence of the trickster. Pcrhaps as a reaction to Fascism's cult of personality, Don Juan ceases to be the protagonist of its own story, and in After the Death of Don Juan the peasants, working both as a collective and as embodied in the main characters of Ramón and Diego naturally emerge as the central characters of the novel. A recurrent theme in most versions of the Don Juan legend is the criticism of the moral hypocrisy of the upper classes, starting with the title character, who abuses his class privileges in order to seduce women from all social strata. While it is true that the libertine's reckless behaviour is seen as exceptional rather than typical, in Tirso's and Molière's plays, and in Mozart and Da Ponte's opera, nobles and landowners are depicted as hypocrites who only profess their religion in public, but 
are as immoral as Don Juan in their private lives. It is only the peasants (and, depending on the version, Don Juan's servant Leporello) who seem to have moral standards. Sylvia Townsend Wamer's After the Death of Don Juan follows this convention: in general, the villagers of Tenorio Viejo are characterized in a much better light than Don Saturno and his son and the guests of the castle. However, her novel is focused on criticising social structures rather than behaviours, and while at the beginning it may resemble a comedy of manners, by the end of the story the focus is almost exclusively on class conflict ${ }^{3}$. The writing of After the Death of Don Juan involved significant historical and literary research. The work displays Warner's knowledge of the tradition of the myth of Don Juan, but also of Spanish history, literature and art of the eighteenth century. It references a political crisis in the reign of Charles III - the 1766 'mutiny of Esquilache'- and the social reforms he attempted to institutionalise. It depicts a stark difference between urban and rural areas, and pictures a country in a state of decay and still holding on to a past of military grandcur. Don Saturno's soliloquies-perhaps also a testimony of the novel's dranatic origins-while impossibly hyperbolic in their attempt to connect the history of literature and art with the Spanish character, show Warner's effort to investigate the concepts and the texts that influenced Spanish cultural identity, and her preoccupation with ideas of tradition and heritage. Among other cultural and historical sources, Warner relied on one of the most popular travel books written about Spain, Richard Ford's A Handbook for Travellers in Spain, which was published in 1845. In a letter written in 1938, Warner recommended Ford's book to Elizabeth Wade White, who intended to travel to the country at war, and acknowledged her debt to Ford's narrative: 'some passages of it may remind you, a little too powerfully for reputation, of After the Death of Don Juan. But I whistle the thought off, and reflect how much you will enjoy the gentleman'4. The influence of Ford's book, which describes routes through Spain by road and sea, can be traced in the novel's portrayal of the 
arid rural landscape and the initial passages that narrate the journey of Ottavio and Ana from Seville to Don Saturno's castle, travelling along the bare and uneven roads and passing through isolated and deprived villages. Warner may have especially agreed with Ford's description of the Spanish peasants, whom he depicts as 'superior to those who arrogate to themselves the title of being their Betters, and in most respects...more interesting. The masses, the least spoilt and the most national, stand like pillars amid ruins, and on them the edificc of Spain's greatness must be reconstructed' (1847, p.xviii). In addition, Warner was also familiar with George Borrow's popular travelogucs5. One of Borrow's most successful books was The Bible in Spain (1843), a romanticised account of his five-year stay in the country as an agent of the Bible Society. Interestingly, like Ford, Borrow opens his narrative by explaining that he is solely interested in reflecting the life and customs of the lower classes, and claiming the superiority of the "peasants, shepherds and muletecrs of Spain' over the country's nobility (I843, p. iv). But the fact that Warner's novel was clearly inspired by the Spanish Civil War and written while the conflict was taking place means that contemporary events also became sources of inspiration for the story. I want to suggest that After the Death of Don Juan was inspired by a particular battle of the Civil War: the sicge of the Alcázar of Toledo. The circumstances of the battle offer remarkable parallels with those in Warner's novel, and I argue that they influenced her work not only in terms of plot, but also thematically. What at first seems a strangely anachronistic setting for the narration of a twentieth-century conflict soon turns into a telling framework for dramatising issues of national identity and political crisis in Spain. The battle of the Alcázar of Toledo - then a military academy - took place from July 27 to September 21 1936, when hundreds of Nationalist military men and several pro-Franco families and members of the clergy occupied the fortification. Franco's troops were aware of the strategic and symbolic value of the fortress, which had its origins 
in a Roman palace, then became an Arab fortress, and was later turned into a royal residence in the $11^{\text {th }}$ century after Spain's re-conquest of the territories occupied by the Arabs. The Republican 'workers' militia' tried to win back the castle in an exhausting battle that went on for months. The event was widely reported in the British press. The Times, and the Manchester Guardian, for instance, provided thorough and regular coverage of the incident, publishing dozens of articles following the development of the siege and its aftermath, including photographic reportage. The circumstances surrounding the siege must have seemed intensely anachronistic in the 1930s, and the battle contributed to the persistent image of Spain as a backward country (Shelmerdine, 2007, p. 40 ). The notoriety of the event also inspired the writing of two books which were published in the months following the end of the battle: H.R. Knickerbocker's The Siege of the Alcázar (first published in Philadelphia in 1936, then in London in 1937) and Major Gcoffrey McNeill-Moss's The Epic of the Alcizar (London, 1936). Both works were sympathetic to the Rebel side, and celebrated the victory of Franco's arny. The Epic of the Alcázar was greatly praised in the Times Literary Supplement, with a reviewer stating that 'The tale that he tells is one of the greatest heroism' (May 29, 1937). The story of the Alcázar even inspired juvenile fiction: the prolific novelist Percy F. Westeman fictionalises the siege at the end of his novel Under Fire in Spain (1937). The similarities between the battle of the Alcázar and the besieged castle at the end of After the Death of Don Juan are remarkable. As in Warner's siege of Tenorio Viejo, the besieged Fascist sympathisers who locked themselves up in the Alcázar were mostly representatives of the upper classes and the military. The summoning of Don Tomás, the village priest, to the castle at the end of the story, echoes an event in the Alcázar, in which the inhabitants of the fortification asked for a priest to baptize the children who had been bom inside, and to act as a mediator between them and the besiegers, an anecdote that was also reported in the British press ${ }^{6}$. Even more emblematically, 
the Republican troops that surrounded the Alcázar were named the 'Workers' Militia', but were simply referred to as 'the workers' in the accounts that The Times gave of the event ${ }^{7}$. Finally, the ending of After the Death of Don Juan evokes the conclusion of the siege of the Alcázar, which ended when Franco's troops defeated those of the Republic and freed the inhabitants of the fortification. The occupation of the Alcázar had particular nationalistic undertones for its historical and symbolic meaning. It not only echoed a past time of class-privilege, a manifest rejection of the ideals of equality propagated by the Spanish Republic, but it also evoked a past national grandeur in which military achicvement and religion were closely related. The Christian king Alfonso VI had conquered the city of Toledo in 1085, reclaiming the Arab palace; the Nationalist faction was quick to exploit the echoes of this history. The victory of the Alcázar was repeatedly celebrated by Fascist groups, and become almost ubiquitous in their nationalist propaganda (Basilio 2004, p. 95). The siege of the Alcázar may have also have inspired two of the main themes of Warner's novel: the tension between tradition and reform, and a crisis of national identity that had grown parallel with a political and social crisis. After the Death of Don Juan is set in the seventh decade of the eighteenth century, the century that definitively confirmed Spain's loss of international supremacy and its position as a peripheral empire. Warner's work depicts the Spanish countryside in a matching state of decay, in which buildings are described as 'derelict', the castle of Don Saturno is crumbling and a mere shadow of what it had been, and the earth is scattered with tired olive trees that cannot be replaced because of the lack of funds. Fashion is consistently used in the novel to reflect a country whose prestige and influence were waning. Spanish style is no longer popular for the upper classes anymore, and, to the horror of her duenna Doña Pilar, Doña Ana and her husband Don Ottavio ask her to sew garments with French-style embroidery. After the Death of Don Juan also includes the story of how the progressive king Charles III had recently 
tried to ban the traditionally Spanish male attire of the long hooded cape and wide-brimmed hat-a decree that even caused a mutiny in Madrid - an issue that Don Saturno discusses with Don Ottavio when the latter complains about it at the beginning of the novel: "that Madrid affair about the cloaks and hats? And there I understand your feelings, in fact I share them. One clings to the traditional aspects of Spain.' (Warner 2002, p.46). Change is seen as a threatening possibility: it is not only class privilege that is at stake, but also national identity. While Don Saturno is sharply aware of the contemporary need for social and territorial reform in the country, he is also presented as obsessed with blood continuity and his family's legacy and, above all, with Spanish history and the nature of the Spanish character - with what Chris Hopkins has described as 'a real 'eternal' Spain which can never be satisfactorily recreated in the present' (Hopkins 2006, p. 119). Throughout the novel, Don Saturno discourses on the subject of Spanish identity, a notion that for him is not attached to nationality, since he traces it as far back as Aristophanes and also recognizes it in Molière. His willingness to educate the peasantry and to provide for their future is connected to his belief that they represent the essence of Spanish-ness:

The Spain that he loved, pungent and austere, the Spain he studied in his library ... it was here in these five men talking about water: it would remain, long after his insipid and expensive puppets had gone back to their town-house'.

Wamer 2002, p. 174

Here Don Satumo seems to speak for Warner herself, who, in a dispatch written for Time and Tide, wrote about what she saw as the Spanish peasants' 'natural appreciation for culture' (Wamer 2012, p. 151). However, this romantic vision of the peasants remains a sentimental ideal; his plans for reform never come to term and 
observing the discussion of the peasants only reminds him of his fear of dying without a natural descendant.

Warner seems to have been both repelled and fascinated by the customs of the Spanish upper classes in the twentieth century. In 'Barcelona', her first article on the Spanish war in Left Review, published in December 1936, she focuses her attention on the luxury villas of the north of Barcelona, expressing shock at the open display of valuable possessions, stating how 'the Spanish aristocracy is in a primitive stage of capitalism, it preserves the medieval brag of possessions, it locks up its moncy in gold and jewels and keeps the gold and jewels for display.' (Warner 2012, p. 139). The emphasis on the ostentatious nature of the upper classes highlights their need to reinstate their social status by referring to an archaic idea of nobility. But it is with the character of Don Ottavio that Warner seems most directly to allude to the idea of nobility as a kind of costumed, theatrical perfomance. Don Ottavio, who at the end of the novel had decided to come back to Tenorio Viejo to avenge Doña Ana and kill Don Juan, forgets his duty of honour when he sees the perilous situation of the besieged castle, and is possessed by a sort of class kinship that makes him join Don Juan and fight in the castle. The ambiguity of the meaning of the word 'nobility' seems intentional here:

Don Ottavio felt the blood rushing to his face. His eyes dazzled, his heart pounded. ... An emotion of nobility swept over him, like a drunk man he became aware of himself as a separate being, a figure to be at once admired and pitied. 2002, pp. 264-5

This 'emotion of nobility' seems to parody the sentimental representations of the inhabitants of the Alcázar of Toledo, who remained locked up for three months defending their fortress without water or provisions. For Don Ottavio it is also a moment of selfconsciousness, a reminder of his status as a nobleman, a figure that becomes in his mind both mythical and tragic. 
As in the battle of the Alcázar, which was from the beginning narrated in 'epic' terms and whose occupiers were described as 'heroes' in newspaper reports', there is a dramatic, theatrical quality in the depiction of this passage, and especially in the description of Don Ottavio, whose character seens to come alive only when he sees the opportunity to perform the role of an outdated nobleman fighting for his birth rights.

Warner's novel, and especially the characters of Don Ottavio and Doña Ana, could also be read as a satire of what she saw as the misrepresentation of the political motivations behind the Spanish war by British media. She was not the only one to share that view. In a pamphlet published in 1937, the British novelist Rebecca West also wrote about the pro-Franco bias in the British press:

I read the newspapers .... in which it is assumed that the rebel forces in Spain are a whitc-souled band of patriots, rather like cavaliers in old-fashioned novels for schoolgirls, who are fighting for the preservation of law and order against blood-thirsty barbarians 1936, p.2

West's analysis of these romanticized, novel-like representations of the Nationalist forces may help us to understand Warner's narrative choices in Afier the Death of Don Juan. The historical and literary settings of the novel take on a new meaning if we consider the work as a satire of the depictions of the Nationalist groups as a set of old-fashioned benevolent aristocrats.

In After the Death of Don Juan, Sylvia Townsend Warner exposes the class conflict underlying the Spanish Civil War, describing a society in which tradition thwarts social progress. Mozart and Da Ponte's eighteenthcentury revision of the myth of Don Juan provided the perfect starting point in which to explore the loss of national identity in a time of crisis, with the parallels between the two historical periods emerging naturally as part of the story, rather than being forced into an overt 
allegory. Warner was probably inspired by the circumstances of the battle of the Alcázar of Toledo to give a searching depiction of Spain's complex and often idealised relationship with its own past.

\section{NOTES}

1. In a letter to Nancy Cunard she describes her novel as 'a parable...or an allegory, or what you will, of the political chemistry of the Spanish War, with the Don Juan-more of Molière than of Mozart-developing as the Fascist on the piece' (Warner, 1982, p. 51).

2. Some of her translations of Spanish war pocms are collected in in Valentine Cunningham's The Penguin Book of Spanish Civil War Verse (1980).

3. While Warner's novel is much more explicit in its political content, scveral critics have explored instances of class tension in Mozart's Don Giovanni. Jonathan Miller has noted the lack of class referents in the opera, an ambiguity that is only resolved by the use of titles, such as 'Don' or 'Commendatore' (1990, p. x). Crities have also highlighted the political implications of the composition that marks the climax of the first act of the opera, Viva la liberta!. especially considering that the opera was premiered ten years before the French Revolution. Political interpretations proposed by Anthony Arblaster and others are based on the use of the particular words 'Viva la liberta!', and the emphasis given to them (they are repeated a dozen times). As part of the plot of the story, they refer to Don Juan's open invitation for anybody to visit his house, sardonically mocking the people who are chasing him looking for revenge (Arblaster, 1992, p. 30).

4. Letter from Sylvia Townsend Warner to Elizabeth Wade White, dated September 25, 1938. Box 8, Files 1011. "Elizabeth Wade White Papers". New York Public Library, Manuscripts and Archives Division.

5. Letter from Sylvia Townsend Warner to Paul Nordoff dated March 2, 1940. "Sylvia Townsend Warner Papers 1937-1977". Folder 3. New York Public Library, Manuscripts and Archives Division. 
6. 'The Fight for Toledo'. The Times. September 11, 1936, p. 14.

7. Ibid.

8. The mutiny, that took place in Madrid in 1766, was referred to as the 'Motin de Esquilache', after the name of the minister who enacted it, Leopoldo de Gregorio, Marquis of Esquilache, of Italian origin and who had served Charles III during his previous reign in Napoles. Esquilache intended to forbid the long capes and widebrimmed hats under the reasoning that they helped protect the anonymity of criminals. While the people of Madrid reacted against what they thought was an imposition of forcign fashion, the main cause behind the many riots was the widespread discontent with a previous trade reform sanctioned by Esquilache, which had caused a steep increase of the price of bread. (Gallego, 2003, p. 61).

9. In an article announcing the end of the battle, The Times described the siege as "notable for the courage and persistence of the defence even in the history of a race whose courage has never been in question'. 'Grim End at Toledo'. The Times', September 19, 1936. p.12.

\section{WORKS CITED}

ARBLASTER, A. (1992). Viva la Liberta!: Politics in Opera. London, Verso.

BASILIO, M. (2004). "The Alcázar of Toledo: Ritual, Tourism and Propaganda in Franco's Spain, 1936-1940". Architecture and Tourism: Spectacle, Performance, and Space. D. Medina Lasansky, Brian McLaren, eds. Oxford: Berg.

BORROW, George. (1843). The Bible in Spain. London, John Murray.

FORD, Richard. (1847, first edition 1845). A Hand-Book for Travellers in Spain. London, John Murray.

GALlEGO, J. A. (2003). El Motin de Esquilache, América y Europa. Madrid, Fundación Mapfre Tavera.

HARMAN, C. (1989). Sylvia Townsend Warner: A Biography. London, Chatto \& Windus. 
HOPKINS, C (2006). English Fiction in the 1930s: Language, Genre, History. London, Continumm.

KNICKERBOCKER, H.R. The Siege of the Alcazar. London, Hutchinson \& Co.

MCNEILL-MOSS, G. The Epic of the Alcazar. London, Rich \& Cowan, Ltd.

MILlER, J. (1990). The Don Giovanni Book. Myths of Seduction and Betrayal. London and Boston, Faber and Faber.

MONTEFIORE, J. (1996). Men and Women Writers of the 1930s: The Dangerous Flow of History. New York, Routledge.

SCHMIDT, M and WARNER, V (2002) 'Sylvia

Townsend Warner in Conversation.' First published in $P N$ Review 23, 1981. Reprinted in the Journal of the Sylvia Townsend Wamer Society 2002 pp.43-52.

SHELMERDINE, B. (2007). British Representations of the Spanish Civil War. Manchester, Manchester University Press.

The Times. September 11, 1936.

The Times September 19, 1936.

Times Literary Supplement May 29, 1937.

WARNER, S. T. (1982), Letters. Ed. W. Maxwell. London, Chatto \& Windus. (2002). After the Death of Don Juan. London, Virago.

(2012) 'What the Soldier Said' First published in Time and Tide August 14, 1937. Reprinted in With the Hunted Ed. P. Tolhurst. Norwich, Black Dog Books pp.150-153. (2012) 'Barcelona'. First published in Left Review' December 1936. Reprinted in With the Hunted Ed. P. Tolhurst. Norwich, Black Dog Books pp.136-141.

WEST, R. (1936). 'Grossly Misinformed'. Spain and Us. London, Holbum and West Central London Committee for Spanish Medical Aid.

WESTERMAN, P. (1937). Under Fire in Spain. London, Blackie \& Son Limited 